\title{
Raising Local Architecture Identity through "Gotong-Royong" Work in Bajo Settings in Central Sulawesi, Indonesia
}

\author{
Zaenal Siradjuddin \\ Architecture Department of Tadulako University, Palu, Indonesia \\ Email: ybmtondo@gmail.com
}

How to cite this paper: Siradjuddin, Z. (2020). Raising Local Architecture Identity through "Gotong-Royong" Work in Bajo Settings in Central Sulawesi, Indonesia. Advances in Applied Sociology, 10, 236-255. https://doi.org/10.4236/aasoci.2020.106015

Received: March 6, 2020

Accepted: June 20, 2020

Published: June 23, 2020

Copyright $\odot 2020$ by author(s) and Scientific Research Publishing Inc. This work is licensed under the Creative Commons Attribution International License (CC BY 4.0).

http://creativecommons.org/licenses/by/4.0/

\section{(c) (i) Open Access}

\begin{abstract}
The existence of the Bajo in Indonesia is spread across almost all of the islands. Central Sulawesi is one of the islands with 61 Bajo settlements spread across various districts including Morowali Regency with 31 Bajo settlements. Bajo tribal settlements are unique in terms of the culture of fishing and life (Gotong-Royong) causing the need for evaluation. The uniqueness of the Bajo tribe can be seen from the procedures for building a house and a culture of cooperation (Gotong-Royong) owned. The research method uses value engineering, which consists of several levels, namely: the first stage of the identification process, the second stage of studying the concept of houses and settlements, the third stage of planning and testing design, and the next stage of planning. The results of this study found various patterns of cooperation (Gotong Royong) informing the Bajo community village. The procedure, determining the location of settlements is strongly influenced by the Gotong Royong which is still strong among the Bajo people.
\end{abstract}

\section{Keywords}

Identity, Local Architecture, Gotong-Royong, Bajo Tribe

\section{Introduction}

Indonesia has 64,349 villages scattered throughout the region of Indonesia (Waani, 2011). Whereas urban areas consist of regency/city cities as well as provincial cities and capitals which number no more than 750 cities and townships. The conflict between urban and rural financing is inversely proportional to the financing that a city needs compared to rural financing, according to Doxiadis (1971). Urban financing is $80 \%$ while rural financing is $20 \%$ for all villages in the 
cosmos. In Indonesia, the current financing for urban centers and villages is 90:10, similar to the demand for houses for middle and lower classes which is inversely proportional to the ability to prepare homes for them. The policy of supplying housing for people is the main problem. Because there is a very high gap every year, it is shown by the increasing need for housing that continues to increase while the ability to provide housing is limited. This problem generally occurs in the city, while the problem in rural areas lies in the quality of homes and settlements that are considered to meet the standards of homes and environments healthy, and the tendency to leave the shape of the house that became the identity of the community. Thus a way is needed that enables the improvement of the ability to provide housing, especially for rural communities who do not leave local architecture as the local wisdom they have in development in Indonesia.

\section{The Problem}

An increasing number of housing needs that occur in urban areas cannot be distinguished from increase.

Urbanization flows from villages to cities. Urbanization is high because the number of jobs available in the village is decreasing and a large amount of available land is controlled by urban communities who invest in villages. As a result, villagers lose their jobs, and local architecture experiences degradation or community, which is then abandoned by its adherents.

Different from the Bajo tribe which forbids the community to leave the village where it is located, strong customary rules cause the Bajo settlement to grow. One of the binders is the culture of cooperation which is still strong among the Bajo community. his research question is how the Bajo tribe maintains exploring and enhancing local architectural values, by continuing to develop quality houses and rural settlements and retaining their identity, by optimizing the potential of local culture (in this case Bajo architecture based on Gotong-Royong).

\section{Literature Study}

A literature study is not intended as a theoretical basis for this research but is intended as a background for researchers' knowledge in starting the implementation of this research so that with this knowledge, researchers are considered capable of implementing researchers well. The intended literature review may include: 1) The concept of sustainable pragmatism planning, 2) Local wisdom, 3) Settlement, 4) Social change in traditional communities, 5) The classical theory of social change, 6) Modernization theory.

\subsection{The Concept of Sustainable Pragmatic Planning}

The concept of pragmatic planning has developed very rapidly in the planning dimension, some experts argue to uncover the concept of pragmatism, in ex- 
pressing the influence of US pragmatic philosophy on the development of pragmatism theories about nature, objectives, and planning methods in the planning dimension. The concept of pragmatism explains the main contributions of pragmatic and "neo-pragmatic" philosophers in identifying the influence of pragmatism on the initial concept of planning as a rational process and from the viewpoint of experts such as Friedman, Lindblom, and Schon; about developing "critical pragmatism" aimed at forest guard activists (foresters); and other planning theory contributions in the 1980s and 1990s. Identify the importance of pragmatic ideas in emphasizing the dimension of planning as a practical social learning activity, which must utilize human capacity and promote the ability of humans to transform critical systemic and transformative work in public spaces (Healey, 2009).

The concept of pragmatism contributed a great degree to the development of design taken from pragmatism thinking. The line of pragmatism thinking is referred to as a broader examination of how the main concepts of design thinking resonate with John Dewey's pragmatic philosophy. The argument presented shows that there is a great degree of convergence between pragmatic perspectives and design thinking. Pragmatism offers an articulation of concerns that are important for designing pragmatic thoughts and perspectives that are easily developed and coherent that can be valuable at theoretical and practical levels. At the theoretical stage, this can inform and inspire the development of design discourse. At a practical level, pragmatic concepts can be operationalized to inform and guide planners in design and help us understand and manage the design process (Dalsgaard, 2014).

Thinking about markers can obscure the structure of the holistic paradigm and the holistic planning paradigm that can be followed up to develop sustainability planning and make many approaches to sustainable development planning and deal with policy constraints. Communicating shows something classic and was recognized more than a century ago by pragmatic philosopher William James who thought of development and planning, or for that matter, those who believed in more and better information to overcome the challenges of sustainability and those who depended on the power of something. From several voices, he then argues that the sustainable development approach is based on the philosophy of pragmatism as a means to connect development perspectives and thoughts with planning, policy and sustainability actions. After detailing how the dynamics of thinking and development planning, thinking among proponents of sustainability is translated into several types of understanding and initiatives, pragmatic frameworks for holistic sustainability planning and proposed policy sets. This theoretical record is arguably based on an understanding of pragmatic theories about truth and rationality, integration and basic processes in action, and human experience as a test of public values and priorities for action. This belief contributes to evolution which refers to pragmatic philosophy, which deals with more work in environmental philosophy and highlights the usefulness of pragmatism in building philosophies of sustainable development. If planners 
and democratic community members make efforts towards a shared understanding that it is a process of communication and ongoing interaction between citizens and experts that needs to be maintained in promoting sustainable development. Knowledge must be generated and tested in public, which shows context, and states that the floor has stood side by side with scientific models and statistics, important steps towards sustainability can be made in the overall planning profession (Holden, 2008).

\subsection{Local Wisdom}

Local wisdom owned by a community is an unpatrolled solution and is an interesting point and tends to be a dominant, attractive or magnetic element so that people will have an attachment that becomes the glue between them. A residential district or village has characteristics that are achieved through the physical conditions of the environment and non-physical conditions such as culture, the social life of the community into a stable system and patterned in a place and related to the history of the community. Another aspect of settlements states that they are part of a large area that functions as the center of the group and is an interpretation of a site, land or plot and is transformed into a place where people live. Some environments, which have specific natural characteristics and spatial structures are mentioned to as plains, valleys, and ponds (basins), and these spaces are equipped with natural elements, e.g. topography with owned rocks, plants, and water and is equipped with very important orientations such as the relationship between the site with light, weather and natural conditions that are part of the microclimate.

The colonies, which began in the late 60 s, were defined as a guide to housing for human life. Settlement exists because there are people who know the culture and coincide with the presence of human or cultural civilization.

The construction and shape of the house are considered as an embodiment of the cultural values of the community. The house is realized as a shelter or a place for humans to deal with climate and weather conditions (heat, cold, rain, and wind).

The home is also interpreted as a place to live because it functions as a place of rest, a place to build a family, a place of work, and a symbol of social status (Rapoport, 1969).

Human behavior in responding to homes varies and changes depending on where they are. For traditional societies, houses are associated with several aspects, such as social, cultural, religious, and physical aspects. Thus houses and villages are part of the area where there are residents who occupy them, so that residents take part in work activities, trying to connect with fellow settlers in a community to meet various needs through life activities (Rapoport, 1977).

In some parts of the area, some communities form houses together like architects who also work as workers. Residential areas such as these generally give birth to settlements located in the interior and make building houses as done traditionally by working together and adapting to local customs and their na- 
ture. Community groups that are formed tend to nail down from generation to generation, so think of it as a place of birth or hometown (Zaenal, 2016).

\subsection{Settlement}

Human settlement or village is understood as a place of life and a place of contact (interaction) between humans and humans, humans with nature and humans with natural authority. Thus Settlement becomes a container filled with humans or a physical container where humans dwell. Settlements as human settlements or areas where people get together and live together, building houses and facilities needed in human life. Colonization can be said as a collection of houses inhabited by residents, forming communities and residing, working, and communicating between people in meeting their daily needs. In improver, the formation of settlements should not be described only in three dimensions but must be seen from four dimensions, because five elements of human life always change the character and culture in a unit of time (Doxiadis, 1971).

There are 5 elements of formation of human settlers according to Doxiadis (1971), the five elements are as follows:

1) A village place or container made by environmental elements such as geography, topography, land, water resources, plants, animals and climate or weather. All these factors interact so that they function as villages or settlements.

2) Humans as elements, namely humans who survive in nature and carry out activities, such as bio-logical activities, sensations, perceptions, emotions, and morals related to values and norms held by humans or human groups.

3) The community as a group of people who live together to organize a residential environment, such as forming social strata, forming culture (culture), and forming administrative areas.

4) Protection (shelter) as an ingredient, namely the structure of the container in which some people live, such as housing, community services, business centers, recreation containers, commercial containers, offices.

5) Social capital as an element, namely a natural-made system, and functions as a small town, such as a water supply system for the needs of settlers, roads for transportation, drainage channels, communication networks, electricity networks, and all other physical needs.

The five factors that become resolutions are aspects that must be studied holistically to find the ideal solution (Doxiadis, 1971). Village elements are set apart to maintain a dynamic balance and are expressed differently in each section, at each scale, and during the evolutionary process. The foundation for completing an ecological unit that is hierarchically related to each other from every element that becomes the law in the settlement of a settlement, but is not a simple law of cause and effect, but a statistical law on the effects of change.

When we respect the legal process related to the concept of microcosm in the understanding of ToKaili, it is intended to apply an understanding of the natural patterns of life in smaller environments, such as life at home, in villages, in settlements and large villages owned by ToKaili, the application of the microcosm 
concept in the Kaili community is reflected in every housing unit from the house to the big village. The organization of sacred space which is believed to be a container for natural authorities on a micro-scale in the application of the principle of macrocosm to the microcosmos and the pattern of sacred space in the micro and macro cosmos is believed to provide protection to ToKaili from disasters and protect ToKaili from disturbances, spirits around them. As in a building, usually, there is a blank space that is used to place sacred objects that are believed to be able to ward off the entry of spirits or disasters into the house so that its inhabitants avoid disaster (Zaenal, 2014).

\subsection{Social Change in Traditional Communities}

The discussion of social change cannot be differentiated from the context of western philosophy, especially those related to Greek philosophy. The essence of Greek philosophy is related to the idea of human behavior related to the consistency of their daily lives. An explanation of philosophy is referred to as seven areas: 1) Empirical philosophy which states: human life cannot be told apart from nature, because they realize that they are also part of nature that cannot be separated. 2) Humans first observed the natural surroundings, the biological environment that is closest to human existence. 3) As a consequence of observing the natural environment, ideas emerged about the growth processes of their neighbors, such as growing the presence of sunlight needed, which is a natural center for the human environment. 4) Observing human nature to see of time, such as changes in observing morning, afternoon, evening in seconds, minutes, hours. 5) Growth requires direction because respect is a maturation process experienced by every human being, nature and human creation (civilization). 6) Humans and so learn to discover that biological life has a common pattern of growth. 7) The growth grows with a certain pattern through certain phases, which is called no growth leap, all grow regularly, without systematic and definite steps. Human growth is as an individual through perfect special directions and rules. The resulting ideas evolve through certain phases that form straight lines and are called imaginary lines.

\subsection{The Classical Theory of Social Change}

Classical sociological theory gave rise to three figures (Karel Max, Marx Weber, and Emile Durkheim), which became the basis of the basic theory of the development of sociological theory. Among the hypotheses that arise relating to idealism, materialism and economic systems, surplus value and the dynamics of social change. According to Max Weber, thoughts that influence the theory of social change from the forms of rationalism possessed are groups formed based on certain interests, namely in the configuration of class (economic-based), status (based on conditions and social interests), parties (based on political interests). In thinking rationality, Weber revealed four different views of the model existed among people. Among the existence of rationality that can suffer alone but can also be a reference for people's behavior in their lives (Johnson, 1986). 
The four rationales referred to are disclosed as follows:

- Traditional rationality

Traditional rationality aims to fight for values derived from the traditions of public life (so that some people claim to be non-rational numbers). Every action is always associated with the orientation of life values. And then that the norms of living together feel even stronger, for example, wedding ceremonies are becoming a tradition in almost all ethnic groups in Indonesia.

- Value-oriented rationality

Rational values are understood by the company as a potential life, even if there is no real everyday life that supports them. This use is supported by the behavior of human life and becomes a belief or belief and culture that is rooted in life (tradition), for example, humans collect capital for use in family funeral ceremonies.

- Affective rationality

Affective rationality is a variety of rational that boils down to a very deep emotional connection and is related to some special relationships that cannot be outside the circle, for instance the relationship between husband and wife, mother and child. If one party gets a mistake, then the other party always tries to help.

- Aimed rationality or instrumental rationality

Aimed rationality is the highest kind of rational consideration of the elements of rational choice about the purpose and means of action chosen.

In every culture community (community), there are many elements of rationality that are owned and can be explained. But in many cases the most popular rationality, there is but one, which is followed by many people, for example, economic rationality is often the foremost choice in many communities. And this is an ordinary social change that changes individual behavior contextually.

\subsection{Modernization Theory}

In general, modernization theory can be phrased as a perspective (vision), which is the main analysis model for human factors in a society. Modernization has become a form of commodity among the people, which puts mentality as the cause of change. The human mentality will increase if a community has capital that is practiced to increase local economic production. Modernity is a product of a western civilization that is associated with the presence of science and technology. So that modernity has become an assumption of accuracy that doesn't need to be questioned. Hence the theory of modernization is positioned as a normal science in compiling the development of science as explained by Thomas Khun (2000) (Figure 1).

Modernization theory can be understood from an economic and non-economic point of view expressed by several experts, as revealed by Harrod Domar from an economic perspective which states that: Economic change is determined by high savings and public investment. The problem of underdevelopment is caused due to the lack of accompanying capital. Developing nations that want to 


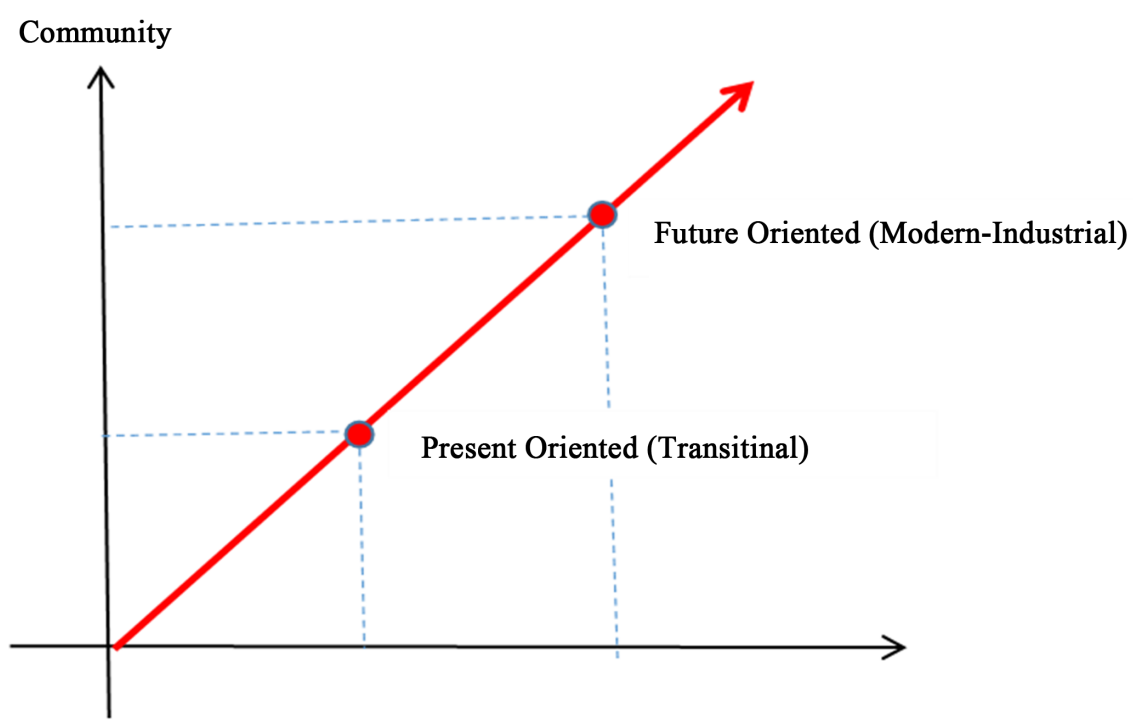

Figure 1. The community in modernization theory by Thomas Kuhn.

advance must seek additional capital, both from within and from abroad.

Meanwhile, from a non-economic point of perspective of Max Weber (Schneider, 1971) states that: human dynamics are shaped by the values of his beliefs. So that gave birth to economic growth (trust relationship with the economy system). Ethical beliefs give birth to high morals and then give birth to a capitalist attitude towards animation. These ethical beliefs become universal values, which may be outside the beliefs themselves, for example, capitalist attitudes are converted to beliefs of cultural values.

In terms of psychology, according to David McClelland (1961) showed his desire to think rationally and work hard between individuals to make everything perfect with their position in the world, it is a continuation of Max Weber's theory. The concept of Need for achievement is a raw spirit that is perfect in the face of work, which then drives the need to succeed. Encouragement not only takes in material rewards but also achieves inner satisfaction. Poverty and underdevelopment in society are because our surrounding is not infected with viruses that are needed to excel.

\section{Method}

Inquiry on the values of local wisdom is carried out using qualitative methods with a value engineering approach, referred to as a systematic and structured decision-making process. Value engineering aims to find the best value of construction activities related to efforts to revive degraded cultural values or the process of returning value related to the function of values in the structure and activities of the construction of houses and settlements to achieve targets related to the efficiency and effectiveness of the functions of a development using sources local power based on local culture that is consistent with the quality and performance required (Hamersley, 2002). 


\subsection{Value Engineering Methods}

The concept of value engineering was built up to provide a way to manage and enhance the value of innovation that gave birth to the competitive advantage of a product by reformulating cultural values through a process of innovation and engineering. The technology focuses on values that aim to achieve optimal balance and consider the relationship between values, functions, and costs in a broader perspective, to achieve more value in uplifting local cultures that are oriented towards resource innovation to produce optimization activities. Only the resulting value cannot be generalized and cannot be accurately defined for all values.

\subsection{Levels of Value Engineering}

The application of value engineering studies is intended to manage and increase the value of physical activities such as the value of togetherness in physical activities and this research, focusing on building activities and settlements for Bajo tribal communities in Central Sulawesi. The value engineering phase consists of six phases, namely: 1). The stage of digging for information, 2). Function analysis phase, 3) The phase of creativity, 4) Evaluation phase, 5) Development phase and 6) the Percentage phase. If the diagram is illustrated as follows (Figure 2).

\section{Discussion}

The study of the policy of developing quality Bajo community homes by raising local identity and optimizing the utilization of local culture, is carried out in several stages, namely: 1) Stage of identification and inventory of social potential and problems of the Bajo tribe as a form of gathering information, 2) The stage

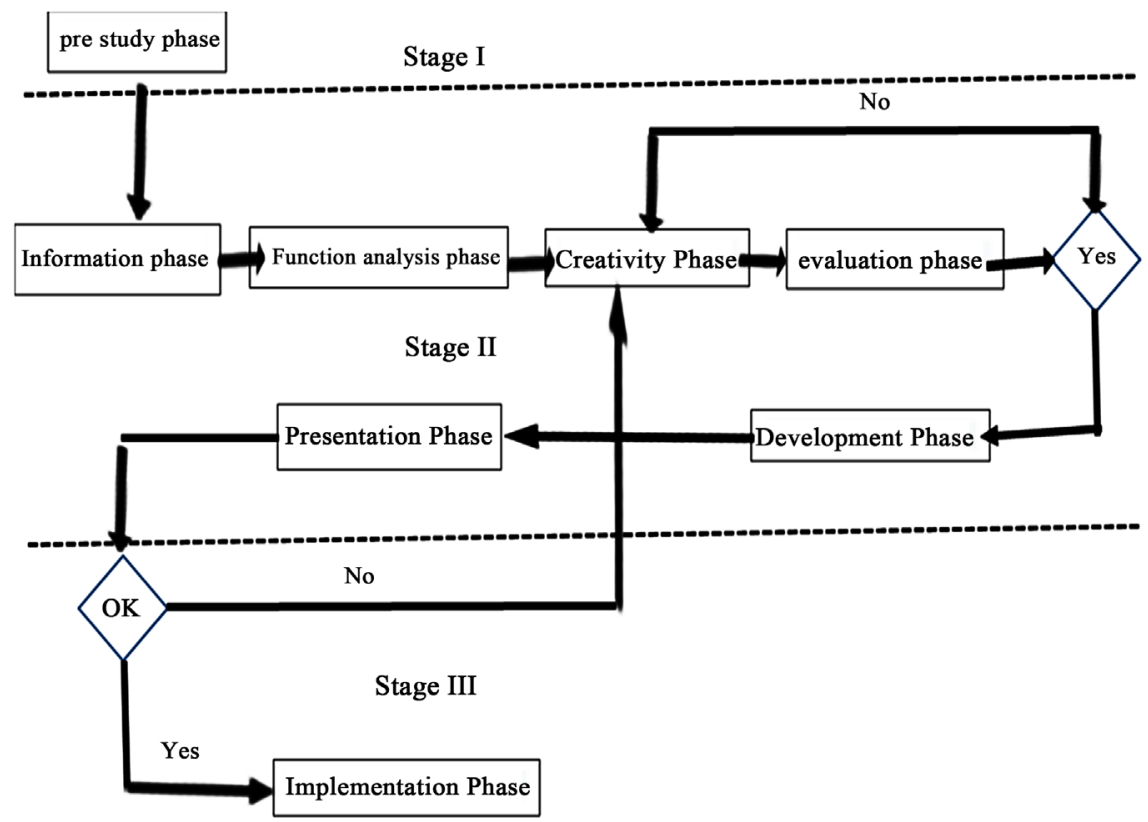

Figure 2. Stages and research process. Source: Ali Muhammad B (2014). 
of excavating the concept of home and local potentials is a form of functional study, 3) Stage of the policy design strategy, as a form of creative activities, 4) The phase of implementing a home policy is the result of an evaluation that is implemented.

\subsection{Identification and Inventory of Potential and Problems of Bajo Tribe}

The effects of the inventory and identification found potentials that can be used as a basis for elevating local culture (local architecture) and some obstacles that require care in the development of the Bajo tribe community. Potential Resources owned by Bajo people are very possible to be posted out to elevate local architecture in this study, such as the peculiarities of work as fishermen catching fish for fish with high economic value, the many potential productive workers available especially from mothers, the work potential of Bajo community cooperation, which tends to be dismissed by the current development. The environmental potential of the Bajo tribe includes the many origins of raw materials that have not been optimized, such as natural raw materials to tidy up the material/stamp duty of the house, the size of the fishing area, the many types of marine products that have not been used optimally. While various weaknesses that have the potential to inhibit the Bajo tribe include: 1) The low-level degree of education of the Bajo tribe (generally the highest level of high school education, and even then the amount is small), 2) Bajo culture is almost extinct, 3) Healthy living practices and behaviors are still below the standard, 4) Sources of income have not varied (limited to fishing), 5) The decline in common work culture in development, causing a low level of participation in development. These potentials and obstacles need to be spoken to maximize the utilization of potential. So the Bajo community development policy will be found towards a prosperous society.

\subsection{Bajo House Development Concept}

Bajo people are unique in building their homes, Bajo people in, building houses divide into three main sections, namely: 1) the site part, 2) the part of the house frame and 3) the part of the housing cover.

\subsubsection{Building Tread Section}

Bajo Houses that stand along the water, require tread processing first, before building their house, the building footprint consists of wooden poles embedded in the seabed, then on the surface, the floor is made as a place of residence of the house, see Figure 3. This form is intended to facilitate the subsequent spelling process.

The formation of a house on seawater shows the availability of land to construct a house on it is the same as the process of preparing land if we build a house on the land.

Figure 3 and Figure 4 show the floor mounted on a pole is a supporting 


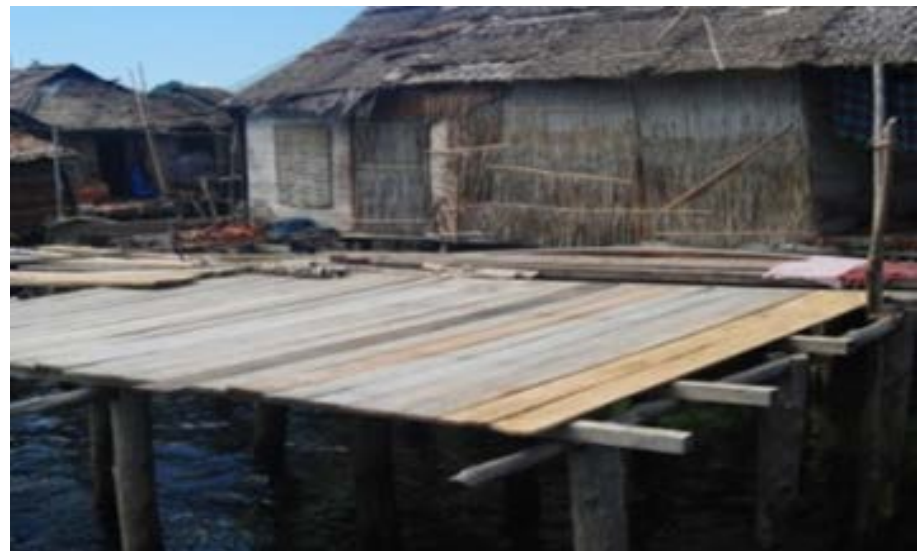

Figure 3. Pole and floor of Ruamah Bajo. Source: Researchers' recorded images in 2009.

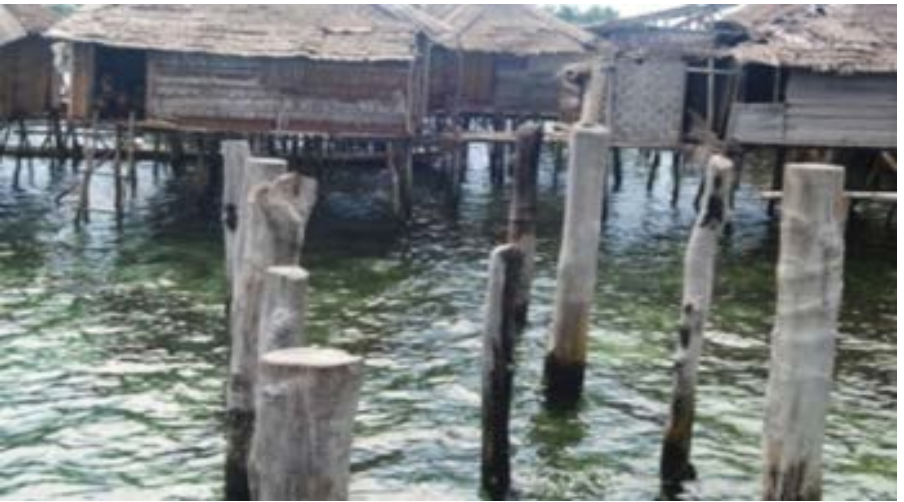

Figure 4. Pole and floor of Ruamah Bajo. Source: Researchers' recorded images in 2009.

building that is ready to be used to build a house, the building pole is then connected to the road that is made as a stiffener that connects to each site, so that the houses are connected, the function of the road as bones behind settlements that bind houses to each other. The road as the back of the settlement has different shapes and materials, some are made of stone and some are made of wood built to connect one house to another.

\subsubsection{Part of House Building Framework}

The building steps consist of blocks of hardwood which are practiced as a structure of Round Wood and processed wood using pen and groove construction and pegs so that the structure can become rigid than the bottom of the building wall first, another way of combining the structure of the wall and the structure of the hood once broad so that the framework of the house building becomes rigid see picture 3 .

Whereas Type, which uses continuous rounded wood material, with poles mounted continuously from the foundation to the hood, as roof support, is generally made without installing the floor first, see Figure 5 .

Other structures and structures made of long logs installed by sticking the logs out so that the wood functions as a pillar supporting the building as well as a pole attached to the building wall, see Figure 6. 


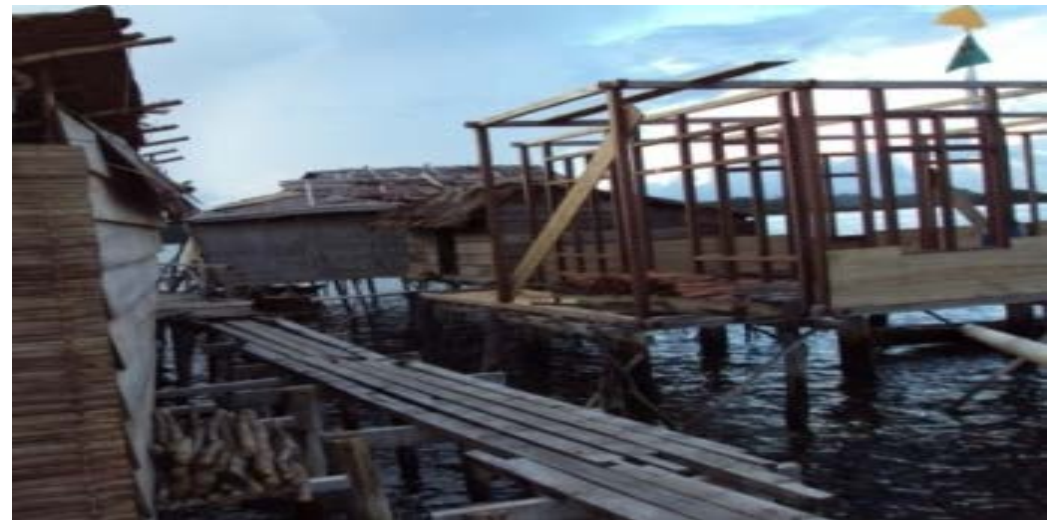

Figure 5. Wooden building framework. Source: Researchers' recorded images in 2009.

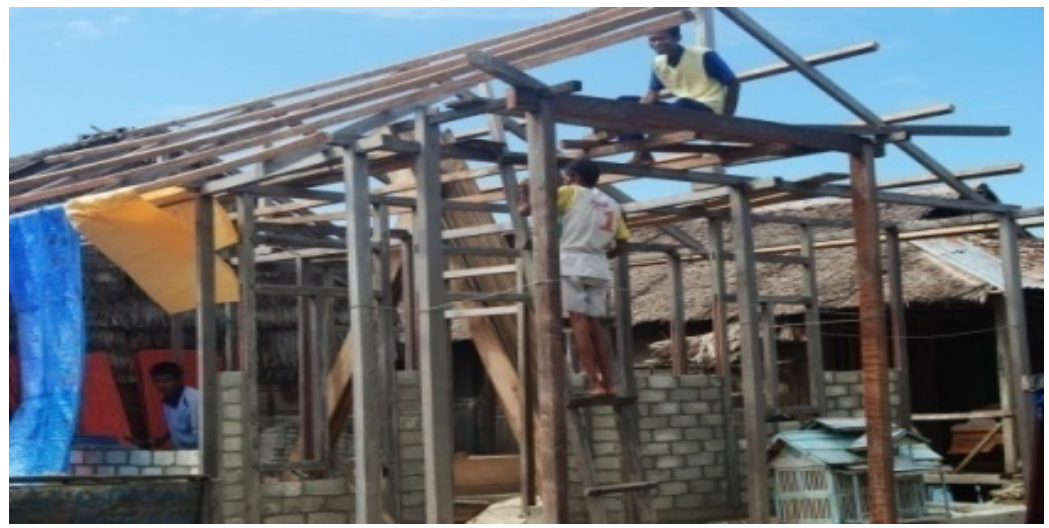

Figure 6. The frame of the building is made of wood with a hood frame. Source: Researchers' recorded images in 2009.

Figure 7 and Figure 8 show two types of structure and construction of a round wooden frame, showing the social status of the community where they are located, a simple type of construction that combines the binding and notch technique using nail ties. This skill is usually done if the implementation of housing construction works with cooperation. While the beam construction uses a handyman (bass) to make it

\subsubsection{Building Closing Section}

The Bajo community-building cover consists of wood and leaf fabric. For wood material, it is ordinarily done by Bajo people who have sufficient ability to buy wood materials and pay carpenters (Bas), so that such homeowners are community groups with high social status in the Bajo community, and are usually owned by traders or customary leaders who have a lot of effort, see Figure 9.

Whereas for working people or middle to lower level, their households are usually made of wooden structures and construction using wall materials made from leaves, namely: Nipa or DaunEnau materials taken from the environment around the area where they live and work collaboratively (Figure 10).

Figure 11 shows the inside of a community house made of leaves plaited and attached to a round wooden post from below. 


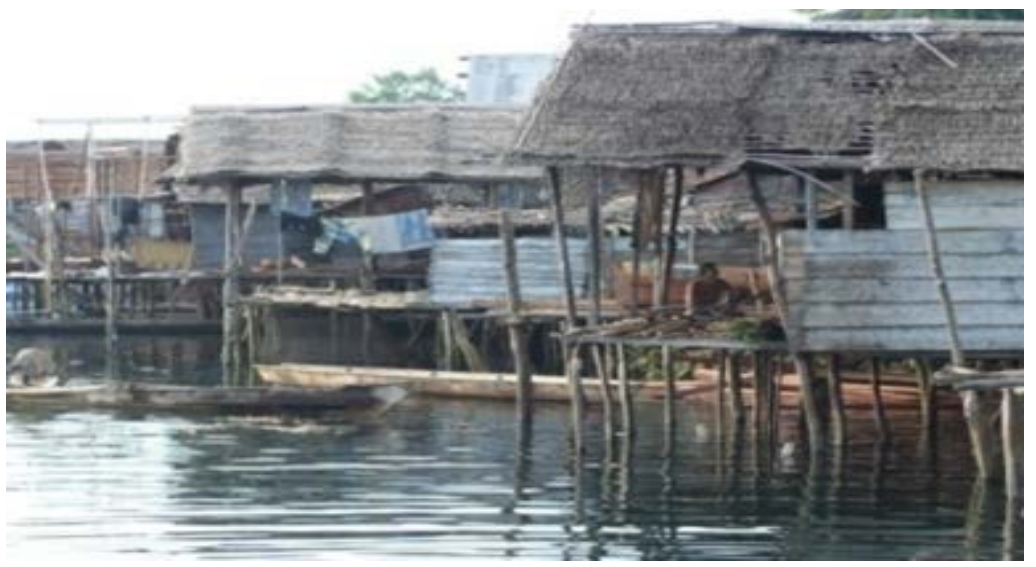

Figure 7. Buildings with continuous wooden frames. Source: Researchers' recorded images in 2009.

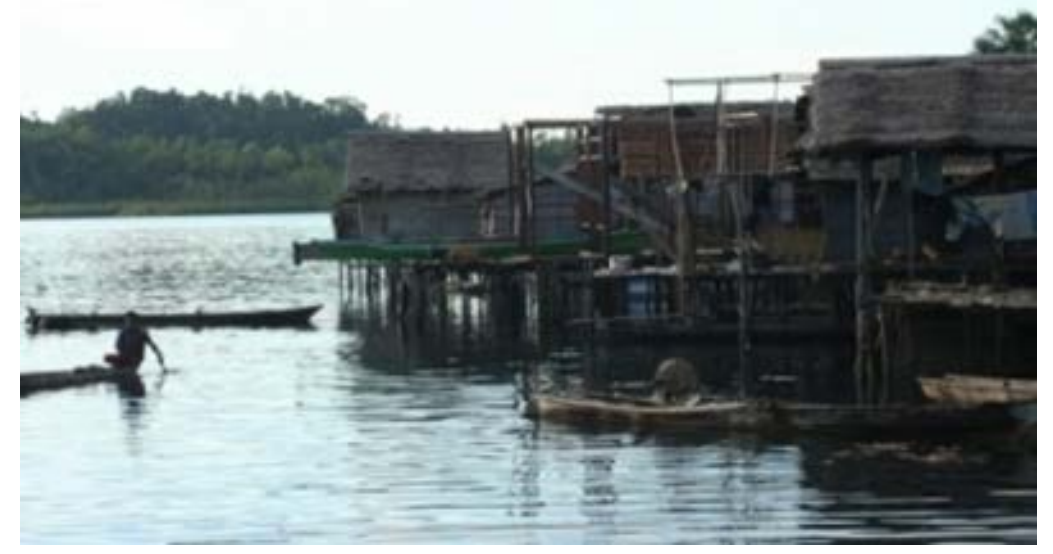

Figure 8. Buildings with continuous frames and hood frames with round wood. Source: Researchers' recorded images in 2009.

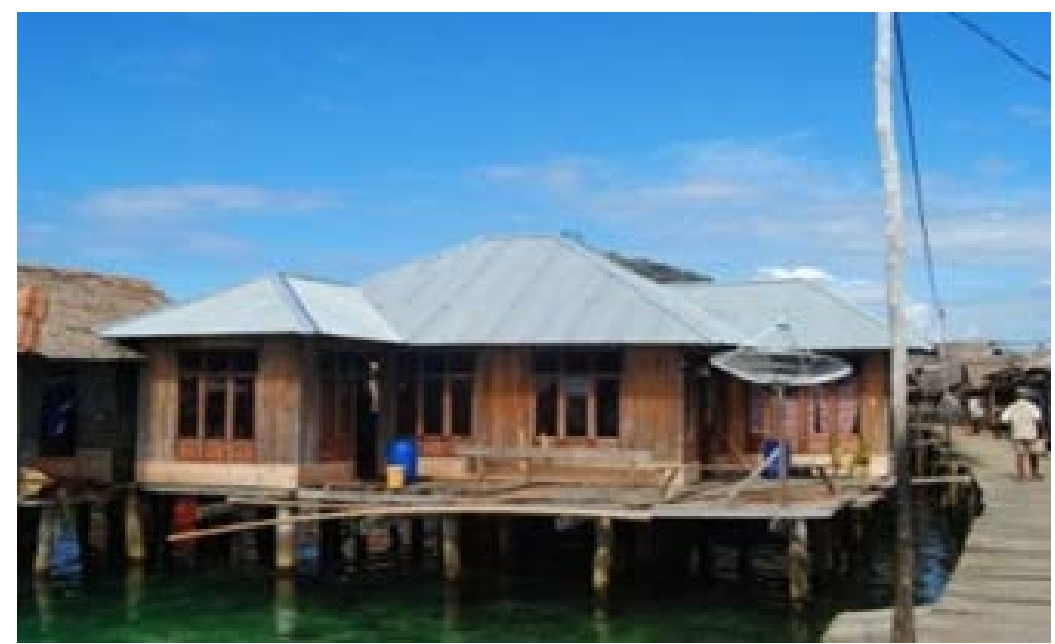

Figure 9. Building cover material from boards made of wood. Source: Researchers' recorded images in 2010 . 


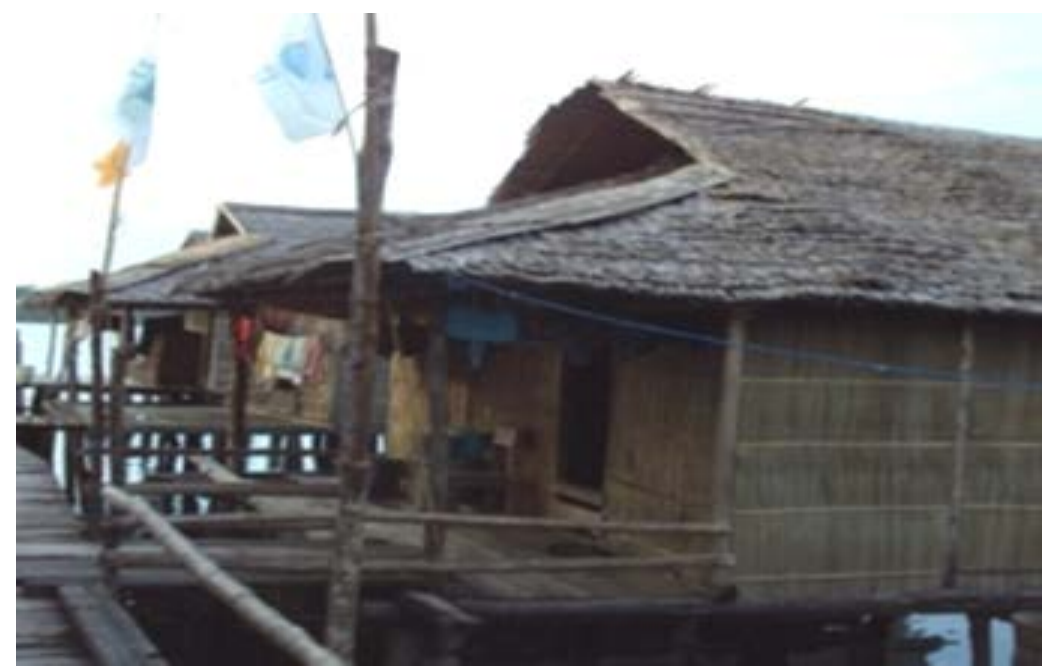

Figure 10. Building cover material from walls made from plaited leaves. Source: Researchers' recorded images in 2010.

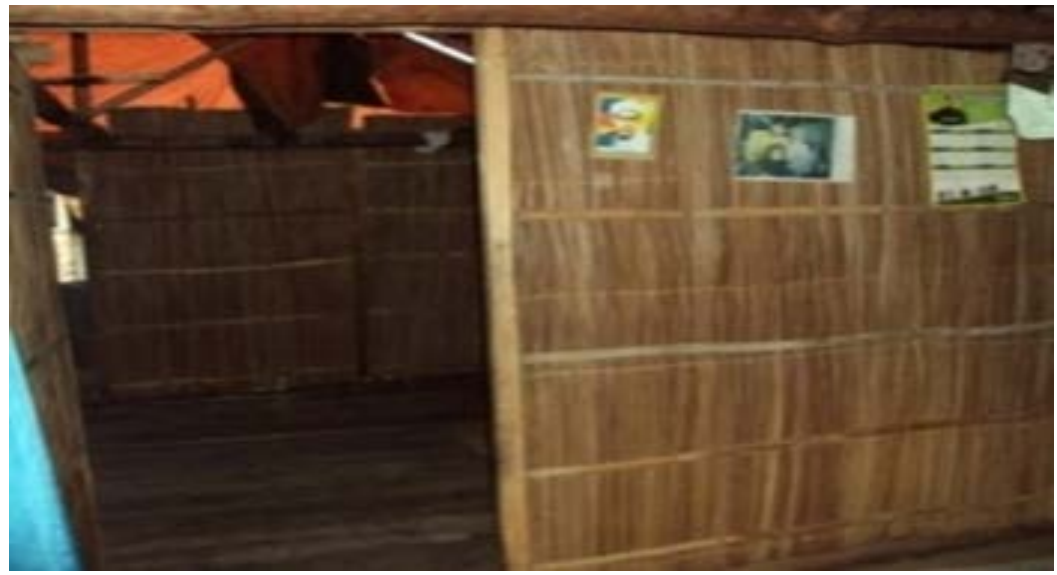

Figure 11. Building cover material the inside uses leaves weaved. Source: Researchers' recorded images in 2010 .

\subsection{Policy Design Strategy}

Formulation of strategic values is used to build strategic thinking, which will establish a strategic policy design strategy. Before shaping the policy design strategy, an assessment of strategic values is needed (Morrisey, 1997). The effects of the assessment are as follows (Table 1).

Based on grounded results of the assessment of strategic values, it was found that several agreed strategic values result vary to range important to very important intervals of houses quality and villages settlement of the Bajo people. The charges are: 1) making Bajo people like to work together, 2) making Bajo people like to develop their skills, 3) making Bajo people love the architecture of the house and the environment where it lives, 4) making the Bajo community prosper. The four missions are strategic formulations of policy in the Bajo community's efforts, reaching their quality homes and settlements and still maintaining their identity as an accomplished marine tribal community. 
Table 1. Assessment of strategic values.

\begin{tabular}{|c|c|c|c|c|c|c|}
\hline \multirow[b]{2}{*}{ Values } & \multicolumn{5}{|c|}{ Interval } & \multirow[b]{2}{*}{ Commentary } \\
\hline & No & Pressing & $\begin{array}{c}\text { Very } \\
\text { important indeed }\end{array}$ & Urgent & $\begin{array}{c}\text { Very } \\
\text { important }\end{array}$ & \\
\hline $\begin{array}{c}\text { Moral } \\
\text { philosophy }\end{array}$ & & & & & & $\begin{array}{l}\text { There is no need for } \\
\text { things that already } \\
\text { live in society }\end{array}$ \\
\hline Character & & & & & & $\begin{array}{l}\text { They must be } \\
\text { considered as a } \\
\text { society that requires } \\
\text { improved welfare }\end{array}$ \\
\hline protection & & & & & & $\begin{array}{l}\text { No need to register. } \\
\text { A very conducive and } \\
\text { family environment }\end{array}$ \\
\hline Surrounding & & & & & & $\begin{array}{l}\text { Very significant to note } \\
\text { because carelessness } \\
\text { committed in society } \\
\text { will damage the future }\end{array}$ \\
\hline Inovasi & & & & & & $\begin{array}{l}\text { Very unnecessary, in } \\
\text { order to bring down } \\
\text { the cost of housing } \\
\text { and residential } \\
\text { development and } \\
\text { optimize the potential } \\
\text { of local materials }\end{array}$ \\
\hline $\begin{array}{l}\text { Community } \\
\text { Image }\end{array}$ & & & & & & $\begin{array}{l}\text { Very necessary, } \\
\text { to develop the power } \\
\text { of the community in } \\
\text { responding to } \\
\text { changes in the global }\end{array}$ \\
\hline $\begin{array}{c}\text { Community } \\
\text { Responsiveness }\end{array}$ & & & & & & $\begin{array}{l}\text { It is very necessary } \\
\text { to optimize human } \\
\text { resource, particularity } \\
\text { women's groups }\end{array}$ \\
\hline $\begin{array}{l}\text { Human } \\
\text { Resources }\end{array}$ & & & & & & $\begin{array}{l}\text { Need to see the } \\
\text { possibility that } \\
\text { develop next }\end{array}$ \\
\hline Probability & & & & & & $\begin{array}{c}\text { Need to consider } \\
\text { the possibilities that } \\
\text { develop next }\end{array}$ \\
\hline $\begin{array}{l}\text { Strategic } \\
\text { alliance } \\
\text { formed }\end{array}$ & & & & & & $\begin{array}{l}\text { Openness is needed } \\
\text { in parliamentary } \\
\text { procedure to form } \\
\text { strategic alliances with } \\
\text { outside groups that are } \\
\text { mutually beneficial }\end{array}$ \\
\hline
\end{tabular}

Source: ${ }^{17}$ HoergeLMorrisey. Processed developed.

\subsection{Household Policy Planning}

Established on the finding of the Bajo community's strategic values, the planning of policies on the quality architecture of houses and settlements by the identity 
of the Bajo tribe becomes a priority in the development of houses and settlements while considering several supporting aspects and inhibiting aspects, namely:

The supporting aspects of insurance plan regarding the quality of housing and residential Bajo are as follows:

1) Cultural aspects of reciprocal cooperation

Cultural aspects in the form of efforts to maintain and intensify cooperation in the Bajo tribal community have existed since their ancestors, only in recent years, cooperation culture is constrained by the inclusion of several development programs that hinder the culture because the program uses a very different principle from participatory cooperation principle, so because it is supported by the government, people tend to leave the cooperation culture, for example, a fishing equipment rock program that is completely irrelevant to their needs but must be accepted, then the assistance is received but not used so much aid is damaged without ever being touched by the community Bajo To support the policy of promoting a cooperation culture, a working group was built from one family that has family ties so that the emotional ties they have can be their glue in conducting joint activities.

\section{2) Pattern aspects of construction a house}

The potential of local materials owned by the Bajo community is a major prospect in developing, building patterns by the Bajo house architecture concept, the development of local materials requires an initiator to support the use of local materials with the use of simple technology so that the methods developed will be able to adapt to the Bajo community's potential.

\section{3) Aspects of optimizing the utilization of local materials}

The architecture of houses and settlements of the Bajo tribe, based on the results of the inventory, found how many groups of people who use $100 \%$ local materials, and some who have used industrial products such as using zinc roofs, metal roof tiles, using brick walls, using ceramic floors, which in general construction is good but most of the level of comfort is not good, because most of which use the manufacturer's material has a relatively high room temperature and high humidity levels so that the level of comfort is less, it is caused by the architecture of houses and settlements are above the water, and the area does not have plants that can protect the building. Buildings that use local materials generally use simple technology so that the show is very temporary compared to using manufactured materials that are very modern and do not blend with the conditions of the Bajo community. Thus there is disharmony with the architecture of the Bajo house.

\section{4) Aspects of simple technological interventions}

The technological backwardness used by the Bajo community is due to the relatively low degree of knowledge which is based on the level of education which is mostly graduated from primary or junior secondary education, only a few are educated to top up let alone to high education. This term causes the architecture of houses and their settlements to be seen as simple buildings and 
tends to be seen as temporary buildings, to develop their buildings; it requires the intervention of knowledge about simple technology that can be used by the community in improving the quality of their houses and settlements.

Besides supporting aspects, other aspects that need to be taken, such as the influence of weather, strong winds, fires and aspects of the availability of abundant local raw materials that require in-depth study in planning, housing development policies, so that the use of local materials can be a marker or characteristic of the Bajo house architecture going forward.

After seeing all aspects described above and the mission carried out by efforts to build quality houses and settlements, the draft policy is as follows:

1) It is necessary to devise a pattern of cooperation work patterns, by the culture of the Bajo community.

2) Diversification of local construction materials/materials is needed, especially finding new materials using appropriate technology that can be introduced into the Bajo community. With the promise of discovering new characteristics of home architecture that are adaptive to the Bajo culture.

3) Enriching the skills of the community in constructing their homes by not leaving the skills that they had before.

4) Build a work climate, which allows simple knowledge can create business opportunities, particularly for group mothers. Because if given by the sea by the husband can obtain additional income which causes an increase in the life of the Bajo tribe.

5) The development of quality Bajo house architecture is required to increase the number of tourist visits as a tourist attraction and the results can develop a prosperous community economy for the Bajo community in the future.

\subsection{Design of Implementation of Community Healthy Houses}

Departing from the Mission and Design of strategies for developing home architecture and healthy housing For the people of Bajo, the concept of healthy home design is divided into 2, namely: 1) Development of cooperation concepts. 2) Design a healthy home by optimizing the utilization of local materials.

\section{1) The concept of reciprocal cooperation}

One of the local wisdom of the Bajo people, which is still owned today is cooperation in performing work. At this time the cooperation activities began to phase along with the increasing harsh influence of a foreign culture that underlies the pattern of capital in society. Today's society is tempted by the lifestyle of consumptive, while the income level is relatively low. To induce the growth of cooperation among the Bajo community, the concept chosen is to grow cooperation starting from the family environment and to be developed in wider family groups, so that the emotional ties of the family can become the bond of cooperation in cooperation.

The frame of cooperation in the family is done by grouping a minimum of five or more and it should be an odd number of groups into a joint venture, a joint venture system is built on cooperation. Then that business capital is not 
always in the form of venture capital, the edge can be in the form of labor capital, and others that are mutually agreed upon. In this case, the joint venture is meant to improve the quality of their homes.

How to develop these joint ventures, after a group, introduce business skills to make panels from the waste materials of palm leaves or nipa whose leaves are used as roofing is used to make wall panels, the ceiling of their homes.

Therefore, not all components of their houses are their engineering products in groups with the pattern of cooperation.

\section{2) Healthy house architectural design concept}

Bajo community homes by the Bajo concept consist of: the site, the character of the building frame, and the wall and roof coverings. The concept can be implemented using $100 \%$ local materials that are closed at Bajo. Wood material that is resistant to seawater is typical because it is a stepped wood and only exists around the Bajo location called the local fainting wood, this wood after being tested is wood with a solid class of one, resistant to only found in the surrounding area they. This wood is used as a floor support pole, and this wood has not so far been recorded in the existing timber, so this is a discovery of a new type of wood.

Building a house frame using a house frame model where the house building consists of a wooden building frame with relatively smaller dimensions so that the use of wood material is more efficient, for example, the largest frame in the form of an $8 \mathrm{~cm} \times 8 \mathrm{~cm}$ beam is located at each meeting wall/or corner space while the frame filler can be in the form of wood with a smaller size $(6 \mathrm{~cm} \times 6$ $\mathrm{cm})$. Similarly, with the manufacture of the roof truss, see Figure 3 and Figure 4 above.

Material for walls and roofs requires modification of what is available, for instance, currently using boards, or woven sailor leaves, replaced with palm frond panels and nipa which are processed into panels using appropriate technology. Technological interventions are meant so that the use of wood can be efficient and effective, and with these materials, all levels of society can reach it and can produce it themselves.

Building roofing materials currently using nipa or palm leaf roofing materials can be replaced by using a layer of bamboo roofing. This alteration is intended, to avoid damage due to the Bajo settlement area or generally Bajo settlements found on the coast get gusts of east and west winds which can cause their roofs to be damaged by the wind. And the historic period of the nipa or any roof is relatively short. By replacing using a bamboo roof, the use of bamboo that is widely available around the island with the age of the roof can be reached out several years later, so that bamboo can be durable then bamboo before it becomes a roof needs to be preserved by soaking in seawater for approximately 2 weeks, see Figure 12.

The function of bamboo material has been utilized by the Kaili community and the Toraja community and some community groups in Indonesia so that the use of bamboo roofs is not impossible in the Bajo community. Figure 13 shows 


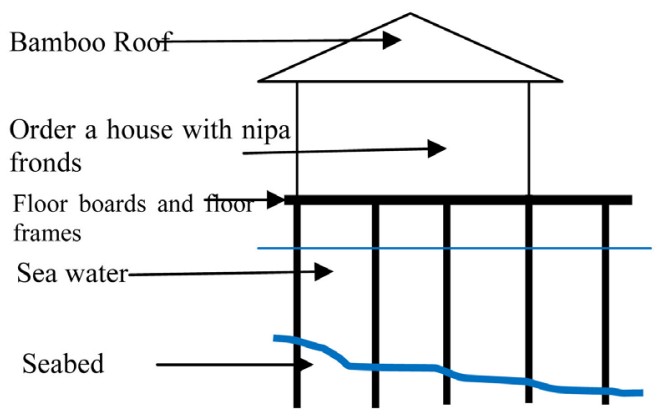

Figure 12. Architecture sketch of Bajo house. Source: Researcher 2020 engineering results.

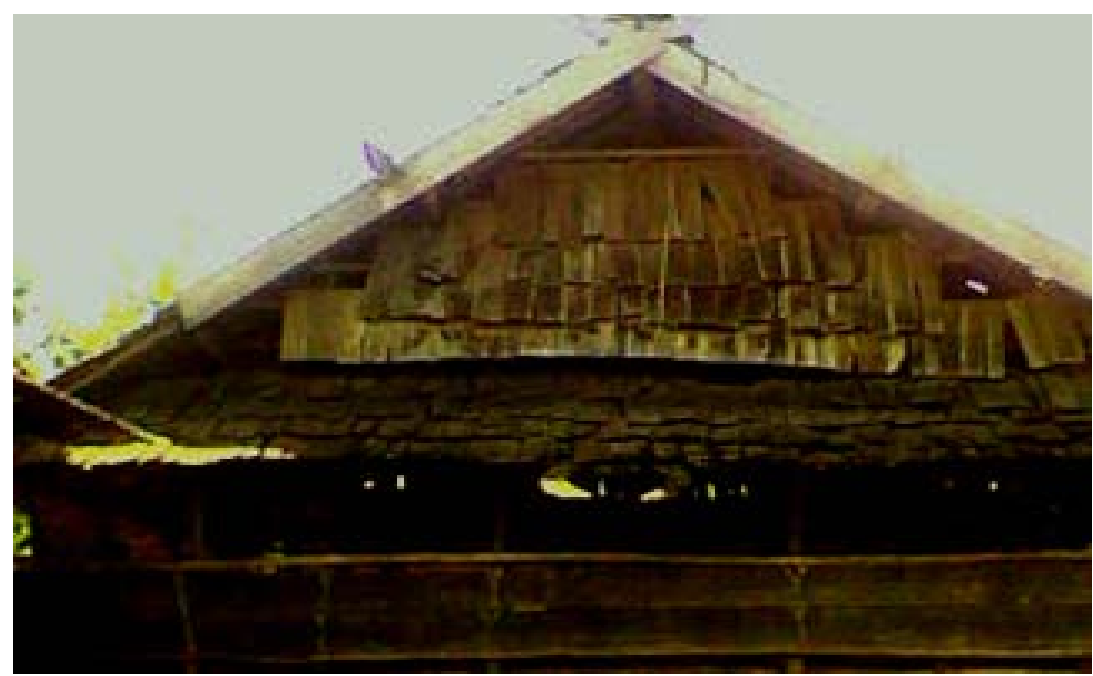

Figure 13. An example of utilizing bamboo as a roof. Source: Researchers' recorded images in 2010 .

the use of bamboo material as a roof on the Kaili community.

\section{Conclusion}

Assessment of the development of quality houses and settlements Bajo Tribe, is as follows:

Encouraging cooperation culture in Bajo Tribe Community is important to improve their prosperity.

Working together is a part of efforts to develop people, the economic system, and the environment which was formerly termed as tribune.

Generate cooperation starting from little groups in one family, then develop cross-family and then cooperating with outsiders Bajo community

Quality lodging and settlement development are built on existing building patterns so that the identity of the Bajo community will be preserved.

The innovation of technology should be adjusted to the development of the skills of the community by taking into account aspects of the quality and service of the house to its inhabitants, as well as the carrying capacity of the settlement of its citizens. 
Develop quality houses and settlements by building up the potential of local materials that are around them, so that they can reduce funding, and provide added value to the community.

The evolution of quality houses and settlements of the Bajo tribe should not be the main object of activity, but should be the final result of Bajo community empowerment. An indicator of the success of housing and settlement development is an increase in welfare that impacts the construction of quality houses and settlements. Because in reality they already have a house but of poor quality.

\section{Conflicts of Interest}

The author declares no conflicts of interest regarding the publication of this paper.

\section{References}

Ali Mohammad, B. (2014). Application of Engineering Value in the Building Industry. Publisher of the Indonesian University of Press (UI Press).

Dalsgaard, P. (2014). Pragmatism and Design Thinking. International Journal of Design, $8,143-155$.

Doxiadis (1971). Ekistics, an Introduction to the Science of Human Settlements. Norwell, MA: Anchor Press, London: Hutchinson \& Co.

Hamersley (2002). Value Management in Construction. Association of Local Authority Business Consultants.

Healey, P. (2009). The Pragmatic Tradition in Planning Thought. Journal of Planning Education and Research, 28, 277-292. https://doi.org/10.1177/0739456X08325175

Holden, M. (2008). The Tough Minded and the Tender Minded: A Pragmatic Turn for Sustainable Development Planning and Policy. Journal of Planning Theory and Practice, 9, 475-496. https://doi.org/10.1080/14649350802481371

Johnson, D. P. (1986). Teori Sociology Classic dan Modern. Di Indonnesiakan Oleh Robert $M Z$ Lawang.

Khun, T. (2000). The Road Science Structure: Philosophical Essay, 1970-1993, with Autobiographical Interview. Chicago, IL: Universities of Chicago.

McClelland, D. (1961). The Achieving Society. Princeton, NJ: Van Nostrand Co.

Morrisey, G. L. (1997). Guidelines for Strategic Thinking, Building Your Planning Foundation, Prenhallindo Jakarta.

Rapoport, A. (1969). House Form and Culture. Englewood Cliffs, NJ: Prentice-Hall.

Rapoport, A. (1977). Human Aspect of Urban Form. Oxford: Pergamum Press.

Schneider, L. (1971). Max Weber: Wisdom and Science in Sociology. The Sociological Quarterly, 12, 462-472.

Waani, Y. O. (2011). Basudara in the South Titiwungen Settlement after the Reclamation of the Manado Beach. Dissertation of the UGM Architecture Department.

Zaenal (2014). Hintuvu Concept on Settlement to Kaili in Central Sulawesi. In International Conference on Sustainable Environmental Architecture (p. 17). Makassar: Department of Architecture Faculty of Hasanuddin University

Zaenal (2016). Re Articulation of Indigenous Bajo in Build Home, Case Village Kabalutan. In International Seminar on Vernacular Settlements (p. 18). Makassar: Department of Architecture Faculty of Engineering at Hasanuddin University. 